\title{
Screening Performance of C-Reactive Protein for Active Pulmonary Tuberculosis in HIV-Positive Patients: A Meta-analysis
}

\section{Andreea-Daniela Meca}

University of Medicine and Pharmacy of Craiova: Universitatea de Medicine si Farmacie din Craiova Maria Bogdan

University of Medicine and Pharmacy of Craiova: Universitatea de Medicine si Farmacie din Craiova Adina Turcu-Stiolica ( $\nabla$ adina.turcu@gmail.com )

University of Medicine and Pharmacy Craiova https://orcid.org/0000-0003-1374-276X

\section{Relu Cocos}

Carol Davila University of Medicine and Pharmacy: Universitatea de Medicina si Farmacie Carol Davila

\section{Bogdan Silviu Ungureanu}

University of Medicine and Pharmacy of Craiova: Universitatea de Medicine si Farmacie din Craiova

\section{Mihaela-Simona Subtirelu}

University of Medicine and Pharmacy of Craiova: Universitatea de Medicine si Farmacie din Craiova

\section{Beatrice Mahler}

Carol Davila University of Medicine and Pharmacy: Universitatea de Medicina si Farmacie Carol Davila

\section{Bogdan-Petre Stanoiu}

University of Medicine and Pharmacy of Craiova: Universitatea de Medicine si Farmacie din Craiova

\section{Elena Camelia Stanciulescu}

University of Medicine and Pharmacy of Craiova: Universitatea de Medicine si Farmacie din Craiova lleana Monica Banita

University of Medicine and Pharmacy of Craiova: Universitatea de Medicine si Farmacie din Craiova

\section{Ana Marina Andrei}

University of Medicine and Pharmacy of Craiova: Universitatea de Medicine si Farmacie din Craiova

\section{Catalina-Gabriela Pisoschi}

University of Medicine and Pharmacy of Craiova: Universitatea de Medicine si Farmacie din Craiova

\section{Research}

Keywords: tuberculosis, HIV-positive, C-reactive protein, sensitivity, specificity, screening

Posted Date: December 18th, 2020

DOl: https://doi.org/10.21203/rs.3.rs-128277/v1 
License: (c) (i) This work is licensed under a Creative Commons Attribution 4.0 International License. Read Full License 


\section{Abstract}

Background: Tuberculosis (TB) is the leading infectious cause of mortality worldwide. In the last years, resistant strains of the etiological agent, Mycobacterium tuberculosis, have emerged, thus demanding more triage tests to identify active pulmonary TB (PTB) patients and to evaluate their disease severity. Therefore, acute-phase reaction serum tests are required for monitoring TB patients, among WHO symptoms screening recommendations. C-reactive protein (CRP) is a non-specific inflammatory biomarker that has been recently proposed for TB screening and can be quantitatively analyzed through cost-effective point-of-care assays. A previous meta-analysis found CRP high sensitive and moderate specific for active pulmonary TB with confirmed HIV infection.

Methods: We performed an update meta-analysis of diagnostic tests, pooling sensitivities and specificities in order to assess the accuracy of CRP as a potential test for the screening of HIV-associated PTB in outpatients. We searched MEDLINE, Web of Science, and SCOPUS, for eligible articles before April $1^{\text {st }}, 2020$.

Results: We identified 9 eligible studies with HIV-positive patients with PTB. At CRP threshold of 10mg/L, CRP pooled sensitivity was $86 \%$ and pooled specificity was $73 \%$. Using CRP threshold of $8 \mathrm{mg} / \mathrm{L}$, pooled sensitivity was $81 \%$ and pooled specificity was $88 \%$. We found that CRP has a high sensitivity in screening of PTB in HIV-positive outpatients, consistent with findings reported previously.

Conclusions: Regardless of pooled specificity, better results were found using the CRP threshold of $8 \mathrm{mg} / \mathrm{L}$ as a test screening of PTB, meeting the need of evaluation of antituberculosis treatment outcomes and reducing resource consumption.

\section{Background}

The evaluation of tuberculosis (TB) is necessary nowadays in order to achieve the World Health Organisation's (WHO) TB strategy targets. Although WHO expects a reduction in the epidemic TB incidence rate of $90 \%$ by 2035 compared with 2015 (which means less than 10 new cases/100.000 individuals), unfortunately, in 2018 the burden of this infectious disease was still high [1,2]. The total global TB incidence in 2018 was 132 new cases/100.000 individuals (7.253.116 new and relapsed TB notified cases), especially in HIV-positive patients (which represented 64\%) $[1,2]$. Even though efforts of improving TB care services have been made in the last years, this major infectious disease remains a worldwide threat, difficult to early diagnose and detect, generating high public transmission rates and mortality [3]. Since 2014, it has exceeded HIV, becoming one of the top-10 causes of deaths globally [4].

This particular need of early bacterial identification is increased by low-adherence antituberculotic regimens: first-line agents represented by isoniazid, rifampicin, pyrazinamide, ethambutol, streptomycin (mostly used in primary active TB), and second-line agents such as fluoroquinolones, aminoglycosides, acid p-aminosalicylic, protionamide, cycloserine, clofazimine, linezolid, bedaquiline, delamanid (mostly used in resistant bacilli strains) [5,6]. Recent growth in both multi-drug-resistant TB forms (MDR-TB - due 
to strains resistant to rifampicin and isoniazid) and extensively drug-resistant TB forms (XDR-TB - due to additional resistance to second-line agents) is caused by improper use of antibiotics and difficult diagnosis procedures which require even more time than primary active $T B$, thus urging the necessity to rapidly and specifically diagnose bacterial TB strains [7-9].

The performance of adequate laboratory methods in the diagnosis of pulmonary tuberculosis (PTB) depends on many factors. First of all, sputum quality and quantity can have impact on the yield of tuberculosis diagnostic results obtained from the microscopic examination of Mycobacterium tuberculosis (M.tb) through the Ziehl-Neelsen method and culture-based technique $[8,10]$. On the other hand, M.tb. requires an elaborated clinical plan in order to be correctly identified and rapidly eliminated, due to the fact that there are more than one mycobacterial strains which can be detected through microscopic Ziehl-Neelsen examination (also called sputum acid-fast bacilli - AFB - test), but only one generates chronic PTB [11]. In other words, sputum microscopy although fast and inexpensive is characterized by low sensitivity $(61 \%)[10,11]$. A sputum-smear negative and/or negative culture does not always exclude TB diagnosis and may lead to wrong TB management [10-12]; that accelerated the use of Xpert Gene MTB/RIF automated rapid molecular assay, which is less sensitive than culture (92\%), as a more sensitive method than sputum smear microscopy for fast identification of PTB as well as rapid assessment of rifampicin susceptibility $[8,13,14]$. Even more, following WHO recommendations to maximize case findings, preclinical evaluation is also based on symptoms screening (WHO 4-SS: presence of at least one in the last 30 days - cough, fever, night sweats, weight loss), characterized by high sensitivity, but reduced specificity, hence low effectiveness in evaluating TB $[11,14,15]$. In order to control TB burden, rapid screening strategies are imperiously necessary, especially in African regions with increasing number of HIV-positive patients in the last years [16].

The particularity of PTB lies in the immunological fight between M.tb. and the host, based on the interaction of bacterial strains and inflammatory biomarkers released by macrophages, monocytes, neutrophils, lymphocytes [17-20]. C-reactive protein (CRP) is also a non-specific biomarker in TB, with highly increased plasmatic concentrations, due to sputum bacillary load and severity of inflammation [17]. Human liver CRP production usually forgoes clinical symptoms [17,18]. CRP can be measured semiquantitatively using capillary blood or quantitatively from either venous or capillary blood through different immunoturbidimetric methods and rapid cost-effective quantified point-of-care tests (POC-CRP assays) which provide results in less than 5 minutes [18,21-23]. On the other hand, in order to correctly implement POC CRP-tests, the program requires a valid quality method, trained certified applicants and continuous internal control based on distributors' manuals [23].

In the past years, there have been published different types of studies (retrospective, comparative, multicenter, clinical trials) that claim the use of CRP as a TB screening test for TB (both pulmonary and extrapulmonary), in various ethnicities, with several comorbid pathologies [16,24-27]. This increased interest in CRP research has determined us to evaluate through statistical analysis if CRP is an adequate screening tool. Recent literature has shown that TB screening could be intensified and improved by using plasmatic CRP concentrations, especially in low-income countries due to the cost-effectiveness of this biomarker 
analysis $[14,16]$. Nevertheless, CRP has also been proposed as a solid candidate for TB screening in HIVpositive patients, providing prognostic values and leading to a more productive disease management $[22,28]$. Shapiro et al. also underlined the importance of CRP as a discrimination factor between culture positive and culture negative specimens [29]. Although CRP does not identify drug resistance, its potential clinical relevance as screening test in PTB patients and as a reliable tool in monitoring treatment outcomes justifies the concept of our study [30].

The objective of this study is to determine the accuracy of the using of CRP as a screening biomarker for TB in adults with HIV infection. Our further question refers to the clinical cut-point of CRP that could indicate a significant inflammation and predicts the presence of PTB in HIV-infected patients. A previous meta-analysis found CRP as a considerable promise tool to ease systematic screening for active TB [31]. Since this previous meta-analysis, new studies have been published. WHO promotes intensified TB case identification in HIV-positive adults by WHO 4-SS; thus we investigated whether rapid CRP tests are more valuable than WHO 4-SS $[11,28,32]$. In order to determine the pooled sensitivity and specificity of CRP test for PTB in outpatients with and without HIV infection we performed a meta-analysis update with other subgroups.

\section{Methods}

This meta-analysis was conducted in accordance with the PRISMA (Preferred Reporting Items for Systematic Reviews and Meta-Analyses) statement. We searched MEDLINE, Web of Science, and SCOPUS, without language restriction to April 1st, 2020, following terms („tuberculosis” AND "C-reactive protein”) OR („tuberculosis” AND „CRP” AND „ screening test” AND “diagnosis”). The study identification also included manual search, with the screening of the citations of the relevant studies. Two review authors (A-D.M. and M-S.S.) independently extracted data using Excel to determine potentially eligible studies. The disagreements were resolved through discussion and, if necessary, consulting a third review author (A.T-S.).

Inclusion criteria to identify studies that directly address the research question were carefully defined: patients were limited to ambulatory patients because hospitalized patients may have different acute inflammatory conditions, other than HIV infection conclusive for our study that could influence the CRP level. The inclusion criteria for selection were studies: a) investigating the CRP in HIV-positive active PTB in adults; $b$ ) including HIV-positive patients with symptoms or reactivated manifestations of PTB; c) including HIV-positive patients who have not previously been on antitubercular treatment; d) consisting original articles, peer-reviewed with randomized controlled trials that evaluated the use of CRP, reporting sensitivity and specificity; e) written in English; and f) including mycobacterial reference standard or/and a composite reference standard diagnosis. Eligible studies in which CRP was measured through quantitative laboratory-based and POC assays were also considered. We only included studies that reported data comparing the index test(s) to an acceptable reference standard from which we could extract true positive (TP), true negative (TN), false positive (FP), and false negative (FN) values. The included studies were selected after reviewing the abstract and full-text for eligibility. 
We included all published manuscripts that primarily assessed CRP levels marking the presence of PTB and also the gold-standard diagnosis criteria for TB. Studies that mentioned GeneXpert MTB/RIF assay or WHO score, sustained by radiographic evidence as diagnosis methods for PTB were also considered for analysis.

We excluded studies that: a) measured CRP through non-quantitative methods or not measured CRP; $b$ ) lacked CRP cut-off values; $\mathrm{C}$ ) discussed comorbid inflammatory conditions in patients without HIV condition; d) diagnosed TB through methods based on inadequate standard reference; e) included patients with extrapulmonary TB or other pulmonary infections determined by a different strain of mycobacteria; $f$ ) included children; g) were written in another language than English and $h$ ) contained data insufficient to easily distinguish between TP and TN cases. If we needed more information (for example, TP, TN, FP, FN at 8mg/l threshold for CRP), we contacted primary study authors for it. The target condition was active PTB in HIV-infected patients, thus we excluded the studies that involved also patients with extrapulmonary TB that cannot be separated.

We appraised the quality of studies using the Quality Assessment of Diagnostic Accuracy Studies-2 (QUADAS-2) tool, which consists of four domains: patient selection, index test, reference standard, and flow and timing (differential verification of TB status for study participants). All these domains were assessed for risk and bias.

We performed meta-analyses to estimate pooled sensitivity and specificity using a bivariate randomeffects model and a Bayesian approach. Random effects models were chosen to describe the variability in test accuracy across studies.

The TP, FP, TN and FN values were extracted from the included studies or the studies' correspondence authors were contacted to provide us with this information. We presented individual study results graphically in forest plots, by plotting the estimates of sensitivity and specificity (95\%Confidence Interval).

Exploratory analyses were undertaken in Review Manager 5 (RevMan 5) and we used R for the definitive analyses. The R-package mada was used for the meta-analysis of diagnostic accuracy. The bivariate model provided a summary receiver operating characteristic curves that integrated receiver operator characteristic curves of primary studies.

We grouped the studies evaluating CRP by the threshold of $8 \mathrm{mg} / \mathrm{l}$ and of $10 \mathrm{mg} / \mathrm{l}$. Mycobacterial culture (solid or liquid) or composite reference standards or bacterial microscopic examination through the ZiehlNeelsen method and fluorescent method were used as reference standard. We investigated the key parameters of summary ROC curves and summary sensitivity-specificity points.

Heterogeneity was investigated through visual examination of forest plots and ROC plots of the raw data. Descriptive statistics included the pooled sensitivity, pooled specificity of the studies, their diagnostic odds ratio (DOR, a measure of the effectiveness of the diagnostic test, higher DOS indicates better test 
performance), Higgins I2 (assess the consistency of the results of studies in meta-analysis: a value of $0 \%$ indicates no observed heterogeneity, and larger values show increasing heterogeneity), and Cochran's Q statistic. We performed $\chi 2$ test to assess heterogeneity of sensitivities and specificities, the null hypothesis being, in both cases, that all are equal for all the studies. The significance level was 0.05 .

Sensitivity analyses was performed by limiting inclusion in the meta-analysis to the studies, for example, that scored as "yes" for the QUADAS-2 question "Did the study avoid inappropriate exclusions?", which expresses low risk of bias for participant selection. Or, another example, the studies that scored "yes" for the QUADAS-2question "Is the reference standard likely to correctly classify the target condition?", which leads to a low risk of bias for the reference standard.

\section{Results}

We identified 9 studies that met the inclusion criteria of our present study (4 new studies since the previous review). Figure 1 shows the flow of studies in the review, with the steps of the study selection process in a PRISMA diagram.

All included studies were performed in countries with a high TB/HIV burden, classified as low-income or middle-income countries (World Bank 2020) as described in Table 1 with the other characteristics of included studies.

The risk of bias and applicability concerns is shown in Figure 2. Most studies had low risk of bias.

Nine studies were included in the meta-analysis that evaluated CRP for PTB among HIV outpatients $[15,16,22,28,29,32-35]$. The studies provided data for 2949 HIV-positive adults, including 601 (20\%) with PTB.

For the CRP's threshold of $10 \mathrm{mg} / \mathrm{L}$, sensitivity estimates ranging between $71 \%$ and $98 \%$, and specificity ranging between $33 \%$ and $96 \%$.

Forest plot and SROC (Summary Receiver Operating Characteristic) curve of CRP sensibility and specificity for PTB for studies among HIV-positive patients, using the CRP's threshold of $10 \mathrm{mg} / \mathrm{L}$ are given in the Figure 3.

The pooled sensitivity was $86 \%$ (95\% Cl: $77-92 \%)$ and pooled specificity $73 \%$ (95\% Cl: $59-86 \%)$, test for heterogeneity $\mathrm{I}^{2}=13.98 \%, Q=9.3, \mathrm{p}=0.318, \mathrm{DOR}=17.5$. The $\chi 2$ test $(\mathrm{p}>0.05)$ and $\mathrm{I}^{2}<50 \%$ suggested nonsignificant heterogeneity of sensitivities and specificities.

For the CRP's threshold of $8 \mathrm{mg} / \mathrm{L}$, sensitivity estimates ranging between $74 \%$ and $90 \%$, and specificity estimates ranging between $69 \%$ and $96 \%$.

Forest plot and SROC curve of CRP sensibility and specificity for PTB for studies among HIV-positive patients, using the CRP's threshold of $8 \mathrm{mg} / \mathrm{L}$ are presented in Figure 4 . 
The pooled sensitivity was $81 \%$ (95\% Cl: $71-89 \%)$ and pooled specificity $88 \%$ (95\% Cl: $69-96 \%)$, test for heterogeneity $\mathrm{I}^{2}=0 \%, \mathrm{Q}=2.309, \mathrm{p}=0.511, \mathrm{DOR}=31.016$. The $\chi 2$ test $(\mathrm{p}>0.05)$ and $\mathrm{I}^{2}<50 \%$ suggested nonsignificant heterogeneity of sensitivities and specificities.

\section{Discussion}

This meta-analysis updates the current literature, including 9 studies, on the accuracy of CRP screening test for PTB in HIV-positive adults [15,16,22,28,29,32-35]. The pooled estimates for sensibility and specificity did not remain similar using a CRP cut-point of $10 \mathrm{mg} / \mathrm{L}$, comparing to the current review (pooled sensitivity $=86 \%$ and pooled specificity $=73 \%$ ) and prior review (pooled sensitivity $=93 \%$ and pooled specificity $=62 \%$, respectively [30].

We chose to evaluate the accuracy of CRP screening test separately for studies that present the results for the threshold of $10 \mathrm{mg} / \mathrm{L}$ vs. $8 \mathrm{mg} / \mathrm{L}$ because the SROC curves do not estimate with respect to the identification of points on the curve that show a particular threshold. The pooled sensitivity was $86 \%$ in the case of $10 \mathrm{mg} / \mathrm{L}$ threshold and $81 \%$ in the case of $8 \mathrm{mg} / \mathrm{L}$ threshold. Better pooled specificity was found in the case of $8 \mathrm{mg} / \mathrm{L}$ threshold: $88 \%$ vs. $73 \%$ in the case of $10 \mathrm{mg} / \mathrm{L}$ threshold.

As WHO recommends, people infected with HIV or living with HIV, should be systematically screened for active TB through WHO-4SS assessment or chest radiography evaluation as a second screen test $[11,36,37]$. Further clinical diagnostic is established by different algorithms: mycobacterial culture, SSM and Xpert MTB/RIF test [11,37]. Although culture is the gold standard for TB diagnosis, it is not usually approached as an initial test, due to longer time required for results ( 2 to 6 weeks) $[11,37]$. Thus, in poor resources and HIV high-prevalence areas, diagnostic algorithms include SSM and Xpert MTB/RIF that provide final results in less than 24 hours [11,37]. Even more, a good TB diagnostic test must have at least $90 \%$ sensitivity and $70 \%$ specificity [37]. Deficiency in screening strategies could lead to delayed TB diagnosis or misdiagnosis, higher rates of transmission and mortality, with disastrous financial consequences [11,37]. Various clinical algorithms have been developed and assessed for management of TB, however these present shortcomings in HIV positive patients [24,27]. Recent studies suggested that CRP presents higher specificity values and a better performance for identification of active PTB, than WHO symptoms-screening strategies $[15,28,36]$. In line with that, our results demonstrate that CRP is an adequate screening test in regions with high prevalence of HIV infections. On the other hand, it is important to note the high quality for retrieved studies with low risk of bias for the QUADAS-2 domains of participant sampling, index test, reference standard and flow and timing for our aim of research.

Although recent research indicates the use of immunological marker CRP as specific enough for distinguished TB diagnosis, this acute-phase protein can be especially relevant for monitoring the severity of the disease or the effectiveness of the treatment $[16,31,32,34]$. CRP can be instantly POC measured, saving time and without posing economic burden in comparison with TB symptoms screening test or other molecular tests $[16,28,31,36]$. On the other hand, the faster PTB is diagnosed, the lower severity and 
mortality caused by this infection, especially in high-risk groups (such as HIV-infected patients) $[15,26,28,31,38]$.

HIV-infected adults are disproportionately influenced by M.tb., due to higher FN rates, lower sensitivity and difficult accessibility in TB-endemic regions of screening tests $[16,24,26,29,32]$. A superior inflammatory response and increased frequency of dissemination have been noticed in HIV-positive TB patients in comparison with non-TB patients, so even though CRP has shown insufficient values of sensitivity and specificity in screening for TB, thus rapid CRP test seems promising for exclusion of PTB in HIV-positive patients $[16,24,28,32]$. As shown, this could further facilitate differential diagnosis that lead to rapid antiretroviral therapy and mortality reduction [28,32]. Moreover, Cicacci et al. confirm that higher bacillary load implies higher CRP levels and underlines a better specificity value of CRP than WHO symptom screening $[15,28,31]$ or other cross-examined plasmatic inflammatory markers [15]. Other studies mentioned the importance of serum analyzed CRP not only as a cost-effective method itself, but also as a potential test for reducing the employment of other molecular tests [15,28,31]. Patients who had higher CRP values were more presumptive to be positive SSM or detected by the GeneXpert MTB/RIF assay, which accentuated the prognostic utility of CRP as a potential screening PTB test $[15,28,35]$.

The importance of establishing a threshold for CRP has also been mentioned, but some researchers emphasize that increasing the values of threshold (for example from 5 to $10 \mathrm{mg} / \mathrm{L}$ ) decreases, even more, the test sensitivity (with more than $10 \%$ ) [29,31,35]. In other words, raising the analysed CRP value could lead to a higher number of TB cases with improper prognostication [29], if other tests are not performed. CRP seems not to be conclusive as a singular TB diagnosis marker, but successful in facilitating systematic TB screening, when associated with the gold-standard reference method or GeneXpert assay, within HIV-positive groups [31]. This is the reason why the evaluation of CRP as a screening biomarker for active PTB has been widely analysed and argued by researchers in the past years $[14,16,29,31,34,35]$ especially since the majority of the infected individuals, children and adults are diagnosed with PTB [3941].

WHO recommends the GeneXpert ${ }^{\circledR} \mathrm{MTB} / \mathrm{RIF}$ assay as the initial diagnostic test in adults and children with presumed HIV-associated TB, rather than conventional microscopy and culture [1,2]. The LoopampTM MTBC Detection Kit is also recommended by WHO as a rapid diagnostic test to detect TB among people with signs or symptoms of TB [1]. There is still no single rapid, accurate and robust TB diagnostic test appropriate for use at the point of care [1], although diagnostics and reducing the time to introduce an adequate therapy are top priorities for WHO [37]. Only the urine-based lateral flow lipoarabinomannan immunocapture assay (LF-LAM) test was recommended in combination with existing TB tests to increase early TB diagnosis and treatment [1].

Our research has several limitations. Most significantly, the reference test characteristics in this metaanalysis were not common across all studies being an important source of heterogeneity. Thus there is no strong reference standard. The different reference standards among the article represent a source of potential bias. We have tried to evaluate separately different reference standards in order to predict the 
level of sensitivity and specificity compared to gold standard reference, but the included studies did not present sufficient data regarding the culture test. The different reference standards could have facilitated for a trade-off between yield of TB screen test and participants included in each analysis.

The outcome of this study could also have introduced bias due to heterogeneous patient population or study design. For example, we evaluated the study conducted by Wilson et. al (2011) that included HIVpositive patients with less than one week of antitubercular therapy in comparison with the other studies that included only patients without previous antitubercular treatment. However, a culture conversion often appears after one up to two or three months of treatment in PTB active patients [12,38], underlining that the consistent modifications in CRP values present low probability to appear after only one week of antitubercular therapy. Another limitation is that all studies were conducted in sub-Saharan Africa, and most studies in a single country (South Africa), particularly to settings with low prevalence of HIV, thus generalization of findings should be performed with care. This is also one of the reasons for heterogeneity in selected reference diagnostic standards of the included studies.

\section{Conclusions}

All in all, CRP could provide essential information regarding antituberculotic treatment outcomes, illness severity and mortality rates and it should be used as a screening method, due to high specificity and sensitivity, to lower the burden of this highly infectious threat.

\section{Abbreviations}

\begin{tabular}{|ll|}
\hline TB & Tuberculosis \\
\hline WHO & World Health Organisation \\
\hline M.tb. & Mycobacterium tuberculosis \\
\hline PTB & Pulmonary tuberculosis \\
AFB & Acid-fast bacilli \\
SSM & Sputum-smear microscopy \\
WHO 4-SS & WHO 4-symptoms screening \\
CRP & C-reactive protein \\
POC & Point-of-care \\
TP & True positive \\
FP & False positive \\
TN & True negative \\
FN & False negative \\
\hline
\end{tabular}

Page $10 / 21$ 


\section{Declarations}

\section{Ethics approval and consent to participate}

Not applicable.

\section{Consent for publication}

Not applicable.

\section{Availability of data and materials}

The datasets used and/or analysed during the current study are available from the corresponding author on reasonable request.

\section{Competing interests}

The authors declare that they have no competing interests.

\section{Funding}

This research received no external funding.

\section{Authors' contributions}

A-D.M., M.B. and A.T-S. participated in research design. A-D.M., M-S.S. and A.T-S. collectively contributed to the data collection. A.T-S. undertook the data analysis and prepared the figures. R.C., BS.U., B.M., B-P.S., EC.S., IM.B. and AM.A. interpret the results from the analysis. A-D.M. and A.T-S. wrote the manuscript. M.B., R.C. and BS.U. review the manuscript. R.C., BS.U. and C-G.P. provided important insights into the manuscript. All authors read and approved the final manuscript.

\section{Acknowledgments}

Not applicable.

\section{Authors' information}

This study is part of the Ph.D. thesis of Andreea-Daniela Meca from the University of Medicine and Pharmacy of Craiova, Craiova, Romania.

\section{References}

1. World Health Organization, WHO End TB strategy. https://www.who.int/tb/strategy/end-tb/en/. Accessed on $23^{\text {rd }}$ May 2020. 
2. World Health Organization, WHO Report 2019.

https://www.who.int/tb/publications/global_report/en/. Accessed on 23 ${ }^{\text {rd }}$ May 2020.

3. Chew MY, Ng J, Lim TK. Diagnosing pulmonary tuberculosis by pooling induced sputum. J. Clin. Tuberc. Other Mycobact. Dis. 2019;15:100100. doi:10.1016/j.jctube.2019.100100.

4. Maru M, Mariam SH, Lobie TA, Gadisa E, Aseffa AT. Prevalence of tuberculosis, drug susceptibility testing, and genotyping of mycobacterial isolates from pulmonary tuberculosis patients in Dessie, Ethiopia. Hindawi Tuberculosis Research and Treatment. 2015;2015:215015. doi:10.1155/2015/215015.

5. Capstick T, Whitaker P. Chapter 41 Tuberculosis. In: Whittlesea C, Hodson K, editors. Clinical Pharmacy and Therapeutics. London, UK: Elsevier, $6^{\text {th }}$ ed.; 2018, p. 673-687.

6. Olliaro PL, Vaillant M. Designing noninferiority tuberculosis treatment trials: Identifying practical advantages for drug regimens with acceptable effectiveness. PLoSMed, 2019;16(7):e1002850. doi:10.1371/journal.pmed.1002850.

7. Ramachandran R, Muniyandi M. Rapid molecular diagnostics for multi-drug resistant tuberculosis in India. Expert Rev. Anti. Infect. Ther. 2018;16(3):197-204. doi:10.1080/14787210.2018.1438262

8. Mertaniasih NM, Soedarsono, Kusmiati T, Koendhori EB, Kusumaningrum D, Koesprijani, et al. Difficulties with the implemented Xpert MTB/RIF for determining diagnosis of pulmonary and extrapulmonary tuberculosis in adults and children. J. Clin. Tuberc. Other Mycobact. Dis. 2020;19:100159. doi:10.1016/j.jctube.2020.100159.

9. Pontali E, Visca D, Centis R, D'Ambrosio L, Spanevello A, Migliori GB. Multi and extensively drugresistant pulmonary tuberculosis: advances in diagnosis and management. Curr. Opin. Pulm. Med. 2018;24(3):244-52. doi:10.1097/MCP.0000000000000477

10. Su WJ, Feng JY, Chiu YC, Huang SF, Lee YC. Role of 2-month sputum smears in predicting culture conversion in pulmonary tuberculosis. Eur. Respir. J. 2011;37:376-83.

doi:10.1183/09031936.00007410.

11. WHO Library Cataloguing-in-Publication Data. Systematic screening for active tuberculosis Principles and recommendations. Geneva, Switzerland: WHO, 2013. https://www.who.int/tb/publications/Final_TB_Screening_guidelines.pdf. Accessed on 2nd June 2020.

12. Rasool G, Khan AM, Mohy-Ud-Din R, Riaz M. Detection of Mycobacterium tuberculosis in AFB smearnegative sputum specimens through MTB culture and GeneXpert® MTB/RIF assay. Int J Immunopathol Pharmacol. 2019;33:1-6. doi:10.1177/2058738419827174.

13. CDC - Centers for Disease Control and Prevention, National Center for HIV/AIDS, Viral Hepatitis, STD, and TB Prevention, Division of Tuberculosis Elimination, Core Curriculum on Tuberculosis, 2013. www.cdc.gov/tb. Accessed on 24 May 2020.

14. Semitala FC, Cattamanchi A, Andama A, Atuhumuza E, Katende J, Mwebe S, et al. Yield and efficiency of intensified tuberculosis case-finding algorithms in 2 high-Risk HIV subgroups in Uganda. J. Acquir. Immune. Defic. Syndr. 2019;82(4):416-20. doi:10.1097/QAl.0000000000002162. 
15. Olsson O, Björkman P, Jansson M, Balcha TT, Mulleta D, Yeba H, et al. Plasma profiles of inflammatory markers associated with active tuberculosis in antiretroviral therapy-naive human immunodeficiency virus-positive individuals. Open Forum Infect. Dis. 2019;6(2):1-9. doi:10.1093/ofid/ofz015

16. Ciccacci F, Floridia M, Bernardini R, Sidumo Z, Mugunhe RJ, Andreotti M, et al. Plasma levels of CRP, neopterin and IP-10 in HIV-infected individuals with and without pulmonary tuberculosis. J. Clin. Tuberc. Other Mycobact. Dis. 2019;16:100107. doi:10.1016/j.jctube.2019.100107.

17. Jayakumar A, Vittinghoff E, Segal MR, Mackenzie WR, Johnson JL, Gitta P, et al. Serum biomarkers of treatment response within a randomized clinical trial for pulmonary tuberculosis. Tuberculosis (Edinb). 2015;95(4):415-20. doi:10.1016/j.tube.2015.04.011.

18. McBride JD, Cooper MA. A high sensitivity assay for the inflammatory marker C-reactive protein employing acoustic biosensing. J. Nanobiotechnology. 2008;6(5):1-8. doi:10.1186/1477-3155-6-5.

19. Zhai W, Wu F, Zhang Y, Fu Y, Liu Z. The immune escape mechanisms of Mycobacterium tuberculosis. Int. J. Mol. Sci. 2019;20(2):340. doi:10.3390/ijms20020340.

20. Zondervan NA, Van Dam JCJ, Schaap PJ, Martins dos Santos VAP, Suarez-Diez M. Regulation of three virulence strategies of Mycobacterium tuberculosis: a success story. Int. J. Mol. Sci. 2018;19(2):347. doi:10.3390/ijms19020347.

21. Scharnhorst V, Noordzij PG, Lutz A, Graser W, Puntener D, Alquezar-Arbe A. A multicenter evaluation of a point of care CRP Test. Clin. Biochem. 2019;71:38-45. doi:10.1016/j.clinbiochem.2019.06.009.

22. Yoon C, Davis JL, Huang L, Muzoora C, Byakwaga H, Scibetta C, et al. Point-of-care C-reactive protein testing to facilitate implementation of isoniazid preventive therapy for people living with HIV. J. Acquir. Immune. Defic. Syndr. 2014;65(5):551-56. doi:10.1097/QAI.0000000000000085.

23. Brouwer $\mathrm{N}$, van Pel J. Validation and evaluation of eight commercially available point of care CRP methods. Clin Chim Acta. 2015;439:195-201. doi:10.1016/j.cca.2014.10.028.

24. Cai R, Yu F, Tao Z, Qian X, Chen J, Lu H. Routinely detected indicators in plasma have a predictive effect on the identification of HIV-infected patients with non-tuberculous mycobacterial and tuberculous infections. Infect. Dis. Poverty. 2017;6:132. doi:10.1186/s40249-017-0347-6.

25. Cudahy PGT, Warren JL, Cohen T, Wilson D. Trends in C-reactive protein, D-dimer, and fibrinogen during therapy for HIV-associated multidrug-resistant tuberculosis. Am. J. Trop. Med. Hyg. 2018;99(5):1336-41. doi:10.4269/ajtmh.18-0322.

26. Hanafiah KM, Garcia ML, Anderson DA. An observational case-control study to determine human immunodeficiency virus and host factor influence on biomarker distribution and serodiagnostic potential in adult pulmonary tuberculosis. Trop. Med. Infect. Dis. 2019;4(57):1-14. doi:10.3390/tropicalmed4020057.

27. Mendelson F, Griesel R, Tiffin N, Rangaka M, Boulle A, Mendelson M, et al. C-reactive protein and procalcitonin to discriminate between tuberculosis, Pneumocystis jirovecii pneumonia, and bacterial pneumonia in HIV-infected in patients meeting WHO criteria for seriously ill: a prospective cohort study. BMC Infect. Dis. 2018;18:399. doi:10.1186/s12879-018-3303-6. 
28. Lawn SD, Kerkhoff AD, Vogt M, Wood R. Diagnostic and prognostic value of serum C-reactive protein for screening for HIV-associated tuberculosis. Int. J. Tuberc. Lung Dis. 2013;17(5):636-43. doi:10.5588/ijtld.12.0811.

29. Shapiro AE, Hong T, Govere S, Thulare H, Moosa MY, Dorasamy A, et al. C-reactive protein as a screening test for HIV-associated pulmonary tuberculosis prior to antiretroviral therapy in South Africa. AIDS. 2018;32(13):1811-20. doi:101097/QAD.0000000000001902.

30. de Oliveira M, Duarte SB, Giacomini G, Marques Pereira PC, de Souza LR, de Arruda Miranda JR, et al. A lung image reconstruction from computed radiography images as a tool to tuberculosis treatment control. J Venom Anim Toxins Incl Trop Dis. 2019;25:e144918, 2019. doi:10.1590/1678-9199-jvatitd1449-18.

31. Yoon C, Chaisson LH, Patel SM, Drain PK, Wilson D, Cattamanchi A. Diagnostic accuracy of Creactive protein for active pulmonary tuberculosis: a systematic review and meta-analysis. Int. J. Tuberc. Lung Dis. 2017;21(9):1013-19. doi:10.5588/ijtld.17.0078.

32. Drain PK, Mayeza L, Bartman P, Hurtado R, Moodley P, Varghese S, et al. Diagnostic accuracy and clinical role of rapid C-reactive protein testing in HIV-infected TB suspects in South Africa. Int. J. Tuberc. Lung Dis. 2014;18(1):20-6. doi:10.5588/ijtld.13.0519.

33. Wilson D, Nachega J, Morroni C, Chaisson R, Maartens G. Diagnosing Smear-Negative Tuberculosis Using Case Definitions and Treatment Response in HIV-infected Adults. Int. J. Tuberc. Lung Dis. 2006;10(1)31-8.

34. Wilson D, Badri M, Maartens G. Performance of serum C-reactive protein as a screening test for smear-negative tuberculosis in an ambulatory high HIV prevalence population. PloS One. 2011;6(1):e15248. doi:10.1371/journal.pone.0015248.

35. Yoon C, Semitala FC, Atuhumuza E, Katende J, Mwebe S, Asege L, et al. Point-of-care C-reactive protein-based tuberculosis screening for people living with HIV: a diagnostic accuracy study. Lancet Infect. Dis. 2017;17(12):1285-92. doi:10.1016/S1473-3099(17)30488-7.

36. Wilson D, Moosa MYS, Cohen T, Cudahy P, Aldous C, Maartens G. Evaluation of tuberculosis treatment response with serial C-reactive protein measurements. Open Forum Infect. Dis. 2018;5(11):ofy253. doi:10.1093/ofid/ofy253.

37. World Health Organization. High-priority target product profiles for new tuberculosis diagnostics: report of a consensus meeting. Geneva, Switzerland: WHO; 2014. http://www.who.int/tb/publications/tpp_report/en/ Accessed on 27 $7^{\text {th }}$ May 2020.

38. Torfs E, Piller T, Cos P, Cappoen D. Opportunities for overcoming Mycobacterium tuberculosis drug resistance: emerging mycobacterial targets and host-directed therapy. Int. J. Mol. Sci. 2019;20(12):2868. doi:10.3390/ijms20122868.

39. Ahmed S, Raqib R, Guðmundsson GH, Bergman P, Agerberth B, Rekha RS. Host-directed therapy as a novel treatment strategy to overcome tuberculosis: targeting immune modulation. Antibiotics, 2020;9(21). doi:10.3390/antibiotics9010021. 
40. Su L, Feng L, Song Q, Kang H, Zhang X, Liang Z, et al. Diagnostic value of dynamics serum sCD163, STREM-1, PCT, and CRP in differentiating sepsis, severity assessment, and prognostic prediction. Hindawi Inflammation in Critical IIIness 2013;2013:969875. doi:10.1155/2013/969875.

41. Chukwunweolu Oshi D, Nakalema Oshi S, Alobu I, Nnanna Ukwaja K. Profile, outcomes, and determinants of unsuccessful tuberculosis treatment outcomes among HIV-infected tuberculosis patients in a Nigerian State. Hindawi Tuberculosis Research and Treatment. 2014;2014:202983. doi:10.1155/2014/202983.

\section{Tables}

Table 1: Characteristics of included studies. 


\begin{tabular}{|c|c|c|c|c|}
\hline $\begin{array}{l}\text { Study } \\
\text { (name, } \\
\text { year) }\end{array}$ & Country & $\begin{array}{l}\text { Number and type } \\
\text { of patients }\end{array}$ & $\begin{array}{l}\text { Methods of TB } \\
\text { screening and } \\
\text { diagnostic } \\
\text { (*reference standard } \\
\text { diagnostic test) }\end{array}$ & $\begin{array}{l}\text { CRP dosing method (assay } \\
\text { kit/analyser type) }\end{array}$ \\
\hline $\begin{array}{l}\text { Ciccaci } \\
\text { et al., } \\
2019 \\
{[16]}\end{array}$ & $\begin{array}{l}\text { Mozambique, } \\
\text { South Africa }\end{array}$ & $\begin{array}{l}\mathrm{n}=143 \\
(21 \text { HIV- } \\
\text { positive/Xpert- } \\
\text { positive + } 122 \\
\text { HIV- } \\
\text { positive/Xpert- } \\
\text { negative) }\end{array}$ & $\begin{array}{l}\text { WHO 4-SS } \\
+* \text { Xpert Gene } \\
\text { MTB/RIF (Assay } \\
\text { system, Cepheid, } \\
\text { Sunnyvale, CA, USA) }\end{array}$ & $\begin{array}{l}\text { Measured before antiTB } \\
\text { treatment through enzyme- } \\
\text { linked immunosorbent } \\
\text { assay - Human CRP ELISA - } \\
\text { Kit (Arigo Biolaboratories } \\
\text { Corporation, Hsinchu City, } \\
\text { Taiwan) }\end{array}$ \\
\hline $\begin{array}{l}\text { Drain et } \\
\text { al., } \\
2014 \\
{[32]}\end{array}$ & $\begin{array}{l}\text { KwaZulu- } \\
\text { Natal, South } \\
\text { Africa }\end{array}$ & $\begin{array}{l}\mathrm{n}=93 \\
(45 \text { HIV- } \\
\text { positive/TB } \\
\text { positive - from } \\
\text { which } 37 \text { culture- } \\
\text { positive and } 8 \\
\text { were SSM- } \\
\text { positive and } 48 \\
\text { HIV-positive/TB- } \\
\text { negative) }\end{array}$ & $\begin{array}{l}\text { *culture (both liquid } \\
\text { BACTEC TB } 960 \\
\text { systems and solid) + } \\
\text { SSM (both Ziehl- } \\
\text { Neelsen and } \\
\text { Auramine } \\
\text { fluorescent staining) } \\
+ \text { WHO 4-SS + chest } \\
\text { radiography } \\
\text { evaluation }\end{array}$ & $\begin{array}{l}\text { Measured before antiTB } \\
\text { treatment through both } \\
\text { immunoturbidometric } \\
\text { assay with Dimension RXL } \\
\text { analyser from Dade- } \\
\text { Behring (Deerfield, IL, USA } \\
\text { - laboratory-based high- } \\
\text { sensitivity method) and } \\
\text { immunoassay POC } \\
\text { (NycoCard CRP test - Axis- } \\
\text { Shield, Oslo, Norway) }\end{array}$ \\
\hline $\begin{array}{l}\text { Lawn } \\
\text { et al., } \\
2013 \\
{[28]}\end{array}$ & $\begin{array}{l}\text { Cape Town, } \\
\text { South Africa }\end{array}$ & $\begin{array}{l}\mathrm{n}=496 \\
(81 \mathrm{HIV}- \\
\text { positive/culture- } \\
\text { positive + } 415 \\
\text { HIV- } \\
\text { positive/culture- } \\
\text { negative) }\end{array}$ & $\begin{array}{l}\text { SSM (fluorescent } \\
\text { microscopy) + } \\
{ }^{*} \text { culture (liquid } \\
\text { BACTEC MGIT) + } \\
\text { WHO 4-SS + Xpert } \\
\text { Gene MTB/RIF + } \\
\text { chest radiography } \\
\text { evaluation }\end{array}$ & $\begin{array}{l}\text { Measured before antiTB } \\
\text { treatment through enzyme- } \\
\text { linked immunosorbent } \\
\text { assay - Quantikine (R\&D } \\
\text { Systems Inc, Minneapolis, } \\
\text { MN, USA) }\end{array}$ \\
\hline $\begin{array}{l}\text { Olsson } \\
\text { et al., } \\
2019 \\
{[15]}\end{array}$ & $\begin{array}{l}\text { Ethiopia, East } \\
\text { Africa }\end{array}$ & $\begin{array}{l}\mathrm{n}=260 \\
\text { (130 HIV- } \\
\text { positive/PTB- } \\
\text { positive + 130 } \\
\text { HIV-positive/TB- } \\
\text { negative) - }\end{array}$ & $\begin{array}{l}\text { *SSM + *culture } \\
\text { (liquid) + WHO 4-SS } \\
\text { + *Xpert Gene } \\
\text { MTB/RIF (Cepheid, } \\
\text { Sunnyvale, CA) }\end{array}$ & $\begin{array}{l}\text { Measured before antiTB } \\
\text { treatment through } \\
\text { immunoturbidometric } \\
\text { assay (Bio-Rad } \\
\text { Laboratories, Hercules, CA - } \\
\text { Bio-Plex } 200 \text { reader) and } \\
\text { Magnetic Luminex Assay } \\
\text { (R\&D Systems Inc., } \\
\text { Minneapolis, MN) }\end{array}$ \\
\hline $\begin{array}{l}\text { Shapiro } \\
\text { et al., } \\
2018 \\
\text { [29] }\end{array}$ & $\begin{array}{l}\text { Durban, } \\
\text { South Africa }\end{array}$ & $\begin{array}{l}\mathrm{n}=425 \\
(42 \text { HIV- } \\
\text { positive/PTB } \\
\text { culture-positive + } \\
383 \text { HIV- } \\
\text { positive/PTB } \\
\text { culture-negative) }\end{array}$ & $\begin{array}{l}\text { *culture (liquid } \\
\text { BACTEC MGIT } \\
\text { systems) + WHO 4- } \\
\text { SS + SSM + Xpert } \\
\text { MTB/RIF + chest } \\
\text { radiography } \\
\text { evaluation }\end{array}$ & $\begin{array}{l}\text { Measured before antiTB } \\
\text { treatment through } \\
\text { immunoturbidometric } \\
\text { assay through Roche } \\
\text { Integra analyzer } \\
\text { (Mannheim, Germany) }\end{array}$ \\
\hline $\begin{array}{l}\text { Wilson } \\
\text { et al, }\end{array}$ & South Africa & $n=130$ & $\begin{array}{l}\text { SSM (auramine- } \\
\text { rhodamine } \\
\text { fluorescent }\end{array}$ & $\begin{array}{l}\text { Measured before antiTB } \\
\text { treatment and also } \\
\text { assessed at weeks 2,4 and }\end{array}$ \\
\hline
\end{tabular}




\begin{tabular}{|c|c|c|c|c|}
\hline $\begin{array}{l}2006 \\
{[33]}\end{array}$ & & $\begin{array}{l}\text { (105 HIV- } \\
\text { positive/TB - } \\
\text { culture-positive or } \\
\text { histological } \\
\text { features and } \\
\text { detection of any } \\
\text { mycobacterial } \\
\text { specimen and } 25 \\
\text { HIV- } \\
\text { positive/possible } \\
\text { TB with anti-TB- } \\
\text { treatment } \\
\text { response) }\end{array}$ & $\begin{array}{l}\text { microscopy) + } \\
\text { *culture (liquid } \\
\text { BACTEC MGIT) + } \\
\text { chest radiography } \\
\text { evaluation }\end{array}$ & $\begin{array}{l}8 \text { after antiTB treatment } \\
\text { through } \\
\text { immunoturbidometric } \\
\text { assay (Beckman Coulter } \\
\text { CX7) }\end{array}$ \\
\hline $\begin{array}{l}\text { Wilson } \\
\text { et al., } \\
2011 \\
{[34]}\end{array}$ & $\begin{array}{l}\text { KuaZulu- } \\
\text { Natal, South } \\
\text { Africa }\end{array}$ & $\begin{array}{l}\mathrm{n}=200 \\
(112 \text { HIV- } \\
\text { positive/TB } \\
\text { culture-positive } \\
\text { and } 88 \text { HIV- } \\
\text { positive/extraPTB } \\
\text { or both PTB and } \\
\text { extraPTB) }\end{array}$ & $\begin{array}{l}\text { *SSM (fluorescent } \\
\text { microscopy) + } \\
\text { *culture (liquid }^{*} \\
\text { BACTEC MGIT) + } \\
\text { WHO 4-SS + chest } \\
\text { radiography } \\
\text { evaluation }\end{array}$ & $\begin{array}{l}\text { Measured before antiTB } \\
\text { treatment or after } \\
\text { maximum one week of } \\
\text { antiTB treatment through } \\
\text { immunoturbidometric } \\
\text { assay (Olympus AU640 } \\
\text { and Dade Dimension RXL) }\end{array}$ \\
\hline $\begin{array}{l}\text { Yoon et } \\
\text { al., } \\
2014 \\
{[22]}\end{array}$ & $\begin{array}{l}\text { Mbarara, } \\
\text { Uganda }\end{array}$ & $\begin{array}{l}\mathrm{n}=201 \text { (5 HIV- } \\
\text { positive/PTB- } \\
\text { positive and } 196 \\
\text { HIV-positive/PTB- } \\
\text { negative) }\end{array}$ & $\begin{array}{l}\text { *SSM + *culture + } \\
\text { WHO 4-SS }\end{array}$ & $\begin{array}{l}\text { Measured before antiTB } \\
\text { treatment through } \\
\text { immunoassay point-of-care } \\
\text { (iCHROMA POC-CRP } \\
\text { Reader, BodiTech Med Inc., } \\
\text { South Korea) }\end{array}$ \\
\hline $\begin{array}{l}\text { Yoon et } \\
\text { al., } \\
2017 \\
{[35]}\end{array}$ & $\begin{array}{l}\text { Kampal, } \\
\text { Uganda }\end{array}$ & $\begin{array}{l}\text { n=1177 } \\
\text { (163 HIV- } \\
\text { positive/PTB } \\
\text { culture-positive, } \\
\text { from which } 84 \\
\text { PTB also } \\
\text { confirmed with } \\
\text { Xpert Gene } \\
\text { MTB/RIF positive } \\
\text { and 1014 HIV- } \\
\text { positive/PTB } \\
\text { negative) }\end{array}$ & $\begin{array}{l}\text { SSM (Capilia TB, } \\
\text { TAUNS, Japan or } \\
\text { MPT64 assay, } \\
\text { Standard } \\
\text { Diagnostics, South } \\
\text { Korea) + *culture } \\
\text { (solid Löwenstein- } \\
\text { Jensen and/or liquid } \\
\text { BACTEC MGIT 960) } \\
\text { + WHO 4-SS + Xpert } \\
\text { Gene MTB/RIF } \\
\text { (Cepheid USA) }\end{array}$ & $\begin{array}{l}\text { Measured before antiTB } \\
\text { treatment through } \\
\text { immunoassay point-of-care } \\
\text { (iCHROMA POC-CRP } \\
\text { Reader, BodiTech Med Inc., } \\
\text { South Korea) }\end{array}$ \\
\hline
\end{tabular}

Table 1. Abbreviations and short explanations: TB - tuberculosis; CRP - C-reactive protein; WHO-4SS (4symptoms screening): symptom screen positivity is defined by presence of any current cough, fever, night sweats, weight loss, in the previous 30 days; SSM (sputum-smear microscopy): identification of AFB (acid-fast bacilli), through Ziehl-Neelson method or auramine fluorescent method; culture: can be realized through solid medium (Löwenstein-Jensen) and/or liquid BACTEC MGIT (Mycobacterial Growth Indicator Tube) 960 system;

\section{Figures}




\begin{tabular}{|c|c|c|c|c|c|c|c|c|}
\hline Study & TP & FP & $\mathrm{FN}$ & TN & Sensitivity $(95 \% \mathrm{Cl})$ & Specificity $(95 \% \mathrm{Cl})$ & Sensitivity $(95 \% \mathrm{CI})$ & S pecificity $(95 \% \mathrm{Cl})$ \\
\hline Ciccaci 2019 & 16 & 7 & 5 & 115 & $0.76[0.53,0.92]$ & $0.94[0.89,0.98]$ & & $\rightarrow$ \\
\hline Olsson 2019 & 96 & 29 & 34 & 101 & $0.74[0.65,0.81]$ & $0.78[0.70,0.85]$ & & - \\
\hline Shapiro 2018 & 33 & 118 & 9 & 265 & $0.79[0.63,0.90]$ & $0.69[0.64,0.74]$ & & $=$ \\
\hline Yoon 2017 & 147 & 40 & 16 & 974 & $0.90[0.85,0.94]$ & $0.96[0.95,0.97]$ & & $=$ \\
\hline
\end{tabular}

\section{SROC Plot}

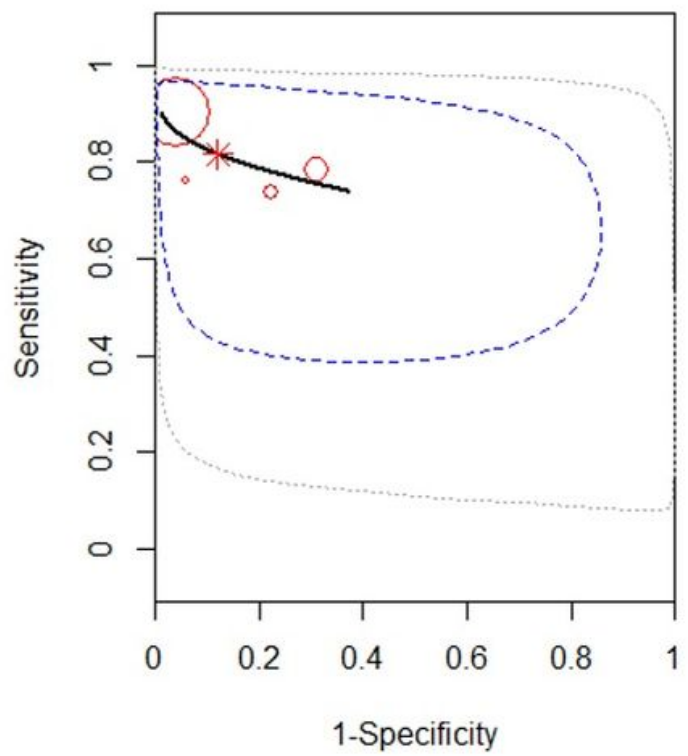

Figure 1

Forest plot and SROC curve (HIV-patients, using the CRP's threshold of 8mg/L). 


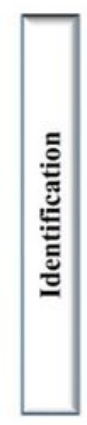

Reasons for exclusion ( $n=303)$ :

- reviews $(n=21)$

- $T B$ as second disease $(n=40)$

- clinical trials $(n=28)$

- observational studies $(n=7)$

- case reports $(n=38)$

- lack of control group $(n=58)$

- poor identification of TB or CRP $(n=23)$

- other diseases than TB $(n=45)$

- other languages $(n=43)$

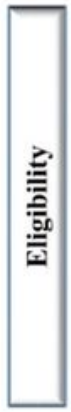

Reasons for exclusion $(n=54)$ :

- meta-analysis $(n=5)$

- studies with children under $15(n=2)$

- abstracts with insufficient data $(n=3)$

- lack of measuring CRP ( $n=5)$

- extrapulmonary TB $(n=17)$

- poor identification of TB $(n=13)$

- groups of patients not clear identified $(n=9)$

\section{Figure 1}

\section{Study flow PRISMA diagram.}




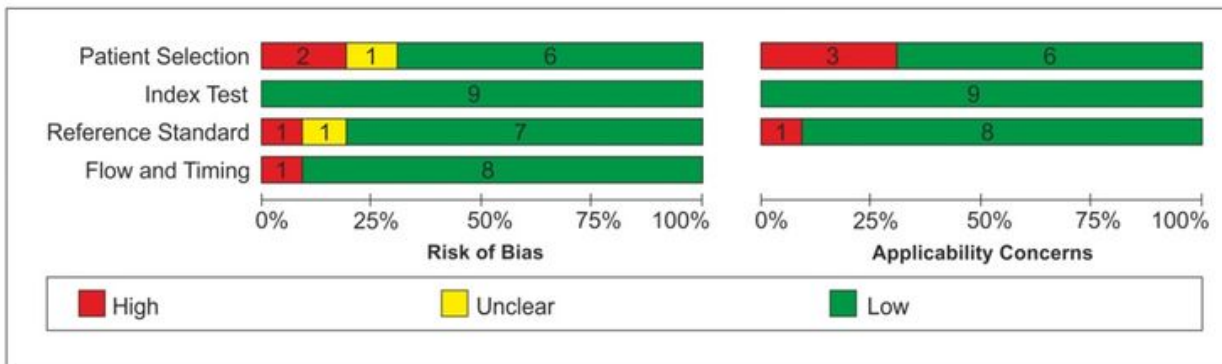

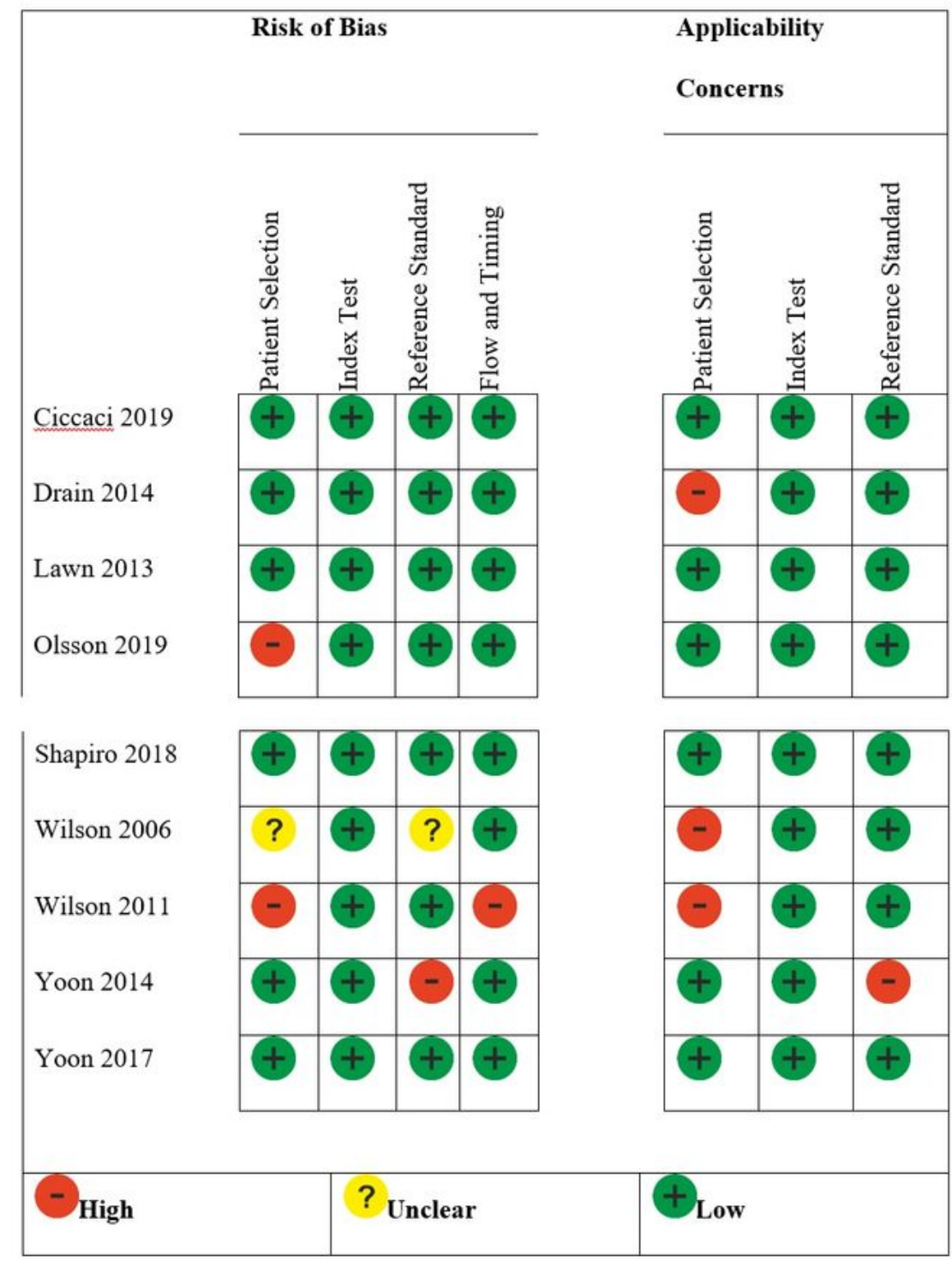

\section{Figure 1}

Risk of bias and applicability concerns summary: review authors' judgments about each study. 


\begin{tabular}{|c|c|c|c|c|c|c|c|c|}
\hline Study & $T P$ & FP & $\mathrm{FN}$ & TN & Sensitivity $(95 \% \mathrm{Cl})$ & Specificity $(95 \% \mathrm{Cl})$ & Sensitivity $(95 \% \mathrm{CI})$ & S pecificity $(95 \% \mathrm{CI})$ \\
\hline Ciccaci 2019 & 16 & 5 & 6 & 116 & $0.73[0.50,0.89]$ & $0.96[0.91,0.99]$ & & \\
\hline Drain 2014 & 44 & 18 & 1 & 21 & $0.98[0.88,1.00]$ & $0.54[0.37,0.70]$ & - & $=$ \\
\hline Lawn 2013 & 69 & 176 & 12 & 239 & $0.85[0.76,0.92]$ & $0.58[0.53,0.62]$ & & $\Rightarrow$ \\
\hline Olsson 2019 & 92 & 28 & 38 & 102 & $0.71[0.62,0.78]$ & $0.78[0.70,0.85]$ & & \\
\hline Shapiro 2018 & 33 & 106 & 9 & 277 & $0.79[0.63,0.90]$ & $0.72[0.68,0.77]$ & & $\Rightarrow$ \\
\hline Wilson 2006 & 57 & 10 & 2 & 5 & $0.97[0.88,1.00]$ & $0.33[0.12,0.62]$ & & \\
\hline Wilson 2011 & 52 & 7 & 2 & 28 & $0.96[0.87,1.00]$ & $0.80[0.63,0.92]$ & - & - \\
\hline Yoon 2014 & 4 & 25 & 1 & 171 & $0.80[0.28,0.99]$ & $0.87[0.82,0.92]$ & & \\
\hline Yoon 2017 & 145 & 283 & 18 & 731 & $0.89[0.83,0.93]$ & $0.72[0.69,0.75]$ & $\Rightarrow$ & - \\
\hline
\end{tabular}

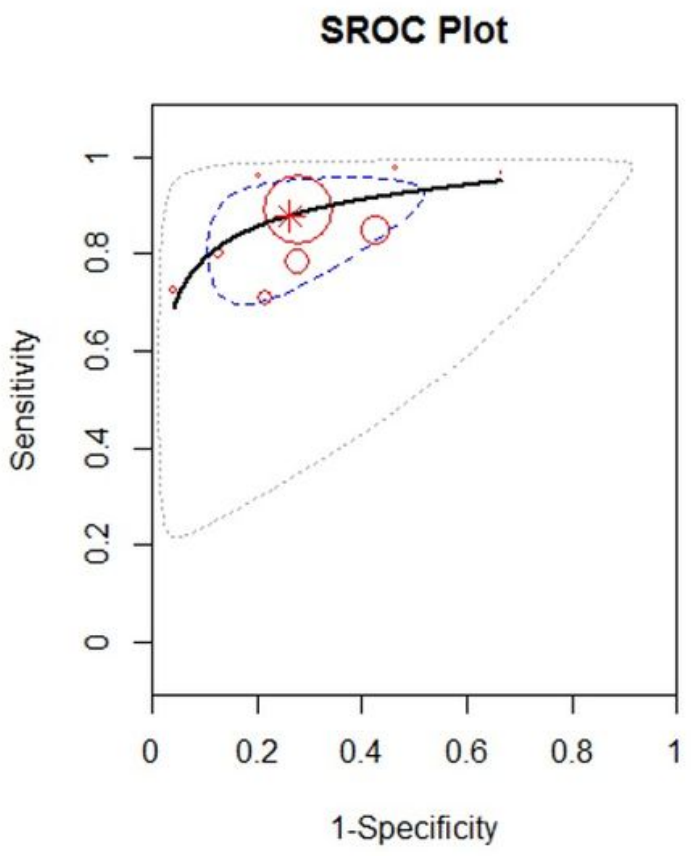

Figure 3

Forest plot and SROC curve (HIV-patients, using the CRP's threshold of $10 \mathrm{mg} / \mathrm{L}$ ).

\section{Supplementary Files}

This is a list of supplementary files associated with this preprint. Click to download.

- PRISMAchecklist.doc 